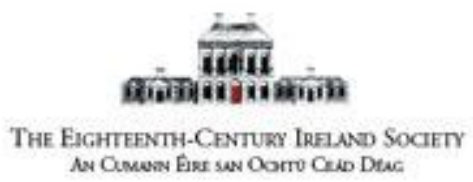

As Comeas Eirs sen Oorro Ceno Dtac

Arthur Murphy and Florida Peat: "The Gray's Inn Journal" and versions of the apolitical Author(s): CONRAD BRUNSTRÖM and DECLAN KAVANAGH

Source: Eighteenth-Century Ireland / Iris an dá chultúr, Vol. 27 (2012), pp. 123-141

Published by: Eighteenth-Century Ireland Society

Stable URL: https://www.jstor.org/stable/24389560

Accessed: 19-08-2019 09:48 UTC

JSTOR is a not-for-profit service that helps scholars, researchers, and students discover, use, and build upon a wide range of content in a trusted digital archive. We use information technology and tools to increase productivity and facilitate new forms of scholarship. For more information about JSTOR, please contact support@jstor.org.

Your use of the JSTOR archive indicates your acceptance of the Terms \& Conditions of Use, available at https://about.jstor.org/terms

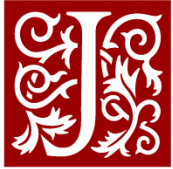

Eighteenth-Century Ireland Society is collaborating with JSTOR to digitize, preserve and extend access to Eighteenth-Century Ireland / Iris an dá chultúr 


\title{
Arthur Murphy and Florida Peat: The Gray's Inn Journal and versions of the apolitical
}

\author{
CONRAD BRUNSTRÖM and \\ DECLAN KAVANAGH
}

$\mathrm{T}$ Towards the end of the 1763 revival of Arthur Murphy's funniest play, The Upholsterer (first performed, 1758), the title character one Quidnunc (an obsessively politicized City tradesman) exchanges words with one Razor (an obsessively politicized City barber) regarding the latest developments in world diplomacy:

\footnotetext{
QUIDNUNC: I have made a rare discovery, - Florida will be able to supply Jamaica with Peet [sic] for their winter firings. I had it from a deep politician.

RAZOR: $\quad$ Ay! I am glad the Poor People of Jamaica will have Florida Peet to burn. $^{1}$
}

This exchange is to be found in Murphy's carefully prepared seven volume edition of his own works, published in 1786. Murphy duly notes that this play was originally performed and published in 1758. However, as scholars of the period will recognize, the mention of Florida peat is a clear reference to the Wilkite controversies of $1762-3$, referring explicitly to Murphy's own embarrassing shortcomings as a political journalist in 1763. Murphy had long been identified with a particular political faction from his early association (from the mid 1750s onward) with the so-called 'Cocoa Tree Cabal', also known as the 'Peace Party' of Lord Bute and Henry Fox. In 1762, Murphy was enlisted as editor and principle author of the pro-ministerial paper The Auditor. John Wilkes and Charles Churchill, authors of the notorious anti-ministerial The North Briton, managed to dupe Murphy into inserting into The Auditor, a ludicrous pro-Bute letter congratulating the government for having negotiated a favourable clause within the Treaty of Paris (1763) whereby Florida farmers would provide

1 The Works of Arthur Murphy, Esq., 7 vols (London, 1786), ii, p. 142.

The Upholsterer, Or, What NEWS? A Farce in Two Acts, As it is now performed at the Theatre Royal in Covent Garden (London, 1763). 
Jamaican plantations with peat. More generally, the letter was intended to satirise the grandiloquent claims made by the Bute administration for the commercial gains of the 1763 treaty:

\begin{abstract}
The only at present unprofitable tracts of Florida, are certain large bogs, or marshy grounds, which produce an excellent kind of fuel; being pretty much the same thing which is called in England peat or turf. Of this there is by far a greater quantity than would serve the inhabitants for firing, were they ten times more numerous then they are. Now, Sir, it is a fact most notoriously true, and of which I have been an eye witness, that all kind of fuel is scarce in the West Indies; .... I can safely affirm that not one of the lower kind of planters have a comfortable fire in their parlours or bed-chambers; nay even amongst the better sort I have seldom seen a good fire, though at the severest season of the year. ${ }^{2}$
\end{abstract}

Murphy took the letter at face value and was immediately mocked for his credulity and his ignorance of the Caribbean climate; credulity that was the more surprising as he had family in the Caribbean and had almost gone there himself to seek his fortune.

The reference to the 'peat' affair in The Upholsterer does not, of course, appear in the first (1758) edition of the play, originally acted four years before Wilkes and Churchill came up with the Florida Peat joke. The premise of the play is, in any case, an expansion of an idea in The Tatler published fifty years earlier (No. 155, 5 April 1710) about a politicized upholsterer concerned about the progress of the War of Spanish Succession at the expense of his own business. ${ }^{3}$ The first edition of Murphy's comedy to make reference to Florida Peat dates from 1763, coinciding with a revival of the play, which ran successfully towards the end of the same year. The 1763 edition inserts a significant stretch of new dialogue carefully leading up to this reference. ${ }^{4}$ Razor's line, quoted above, actually concludes the penultimate scene of the play as both characters leave the stage. It is reasonable to assume that this remark provoked significant mirth and applause, making it appropriate as a scene ending, an uncappable stroke of shameless selfreference on Murphy's part and therefore perfect for bringing down the curtain.

The version of the play included in the 1786 Works retains the Florida Peat reference, only diluting the effect of the joke with a few added lines of less specific radical/patriotic sentiment. The lines are interesting, if only because they clearly show Murphy telling a joke against himself, as this article will demonstrate. The extent of the new writing in 1763 shows the trouble he went to, to enforce this self-mockery, and the retaining of the reference in the 1786 Works reinforces his assertion that politics was an unfortunate early detour in his literary

2 Arthur Murphy, The Auditor, Saturday, December 18, 1762, in John Caesar Wilkes (ed.) The Political controversy, Number X. Monday, December 20, 1762, Vol. II (London: 1762), p. 358.

3 Richard Steele and Joseph Addison, Selections from The Tatler and The Spectator, ed. by Angus Ross (Harmondsworth, 1982), pp. 152-155.

4 Robert Spector has noted the insertion of this reference, but fails to consider the oddity of its inclusion or its larger political implications. Robert Spector, Arthur Murphy (Boston, 1979), p. 73. 
career. Although Murphy is best remembered as a dramatist, in the early 1760 s he was equally well known as a political journalist and theatre audiences were slow to forget Murphy's political affinities. By 1763, Murphy had become famous for his very eclecticism and the sheer variety of occupations he had held. He is introduced in Charles Churchill's phenomenally successful survey of London actors, The Rosciad (1760) accordingly:
Apart from all the rest great M_RP_Y came -
Common to fools and wits, the rage of fame.
What tho' the Sons of Nonsense hail him SIRE,
AUDITOR, AUTHOR, MANAGER, and 'SQUIRE,
His restless soul's ambition stops not there,
To make his triumphs perfect, dub him PLAY'R. ${ }^{5}$

By the time of the Florida Peat controversy therefore, Murphy was famous (or notorious) not only as the editor of The Auditor, but also as someone seemingly incapable of sticking to any one trade, one who had attempted too many jobs to ever establish a coherent career. Acting, like politics, would prove another false start.

In later life, Murphy was extremely successful at covering his political tracks. As he candidly remarks in his introduction to his 'complete works' a quarter of a century later, 'Of the political papers which fell from my pen many years ago, I hope no trace is left.' ${ }^{6}$ Anyone attempting to excavate original issues of The Auditor must confess that Murphy's wishes have been efficiently gratified. While editing this paper, Murphy printed a wholly fictitious story describing how Colonel Cataline (i.e. John Wilkes) had wandered into a Winchester bookshop, accosted the schoolboy son of the Prime Minister, Lord Bute, and informed him that his father would certainly either be beheaded or else lynched within the next six months:

\footnotetext{
Nor would I have COLONEL CATALINE be a manager of the prosecution, but rather turn evidence, for which the reader will think him well qualified, when he has read the following short story, which he may depend is authentic. A young gentleman of 12 years old, who is placed for education at Winchester college, and is son to the noble lord in question, being the other day in a bookseller's shop at Winchester, COLONEL CATALINE entered the place, and most liberally and manfully accosted the youth in these words---."Young gentleman, your father will have his head cut off-----Sir !---I never heard that he has done any thing amiss; he has a great many friends, --- such as $* *_{-\ldots} * *_{\text {-.- }}$ and $* *$.-- and $* * *_{-}$--and the right honourable George * *----------Ay! He is your father's great puppy-dog,--but depend upon it your father will lose his head, or the mob shall tear him to pieces."
}

5 The Poetical Works of Charles Churchill, ed. by Douglas Grant (Oxford, 1956), p. 19.

6 Jesse Foot, The Life of Arthur Murphy Esq. (London, 1811), p. 190.

7 A. Murphy, The Auditor, Thursday, September 30, 1762, in J. C. Wilkes (ed.) The Political Controversy, Number XII. Monday, October, 4, 1762, Vol. II, p. 424. 
The story could not be substantiated and was ultimately retracted. It was at this point that The North Briton extracted revenge by writing an anonymous and ludicrous letter to The Auditor congratulating the Peace Party government for having facilitated such a lucrative deal whereby Florida farmers could sell peat to Jamaica to keep poor West Indians warm.

However it is considered, the insertion of the reference into a new performance and publication of The Upholsterer late in 1763, appears to indicate a strategic determination on the part of Murphy to use self-satire in order to distance himself from his political past, by portraying himself, albeit only fleetingly, as a blustering reactionary counterpart of the libertarian Quidnunc in an effort to forestall some of the political hostility that had started to dog his career(s). The version containing the joke appears some months after Murphy had decided to give up political journalism but well within the political memory of his audience. From 1763 onwards he would continue to claim that politics were essentially alien to his character, but would no longer contaminate this assertion by writing for ministerial hire and would do his utmost to cleanse his literary legacy from the imputation of factionalism. However, John Brewer has noted that a year later, in 1764, a visit by George III to Drury Lane to see Murphy's play All in the Wrong, still provoked the Wilkite crowd to cheer 'Let us be all in the right! Wilkes and Liberty!'8 Evidentally, Murphy's association with the Bute administration could not be disentangled from his literary reputation so quickly or easily.

As a farce, The Upholsterer was extremely popular in its own day, and it still reads well, despite its obvious reactionary bias. Murphy's play is bitterly if amusingly scathing of attempts by ordinary people to interest themselves in political affairs. Indeed, David Garrick is said to have originally refused to perform the role of Quidnunc (whose name literally means 'What now?/What news?), not wishing to get involved in an aggressively 'political' play. Unlike Murphy, Garrick at least recognized that being polemically 'apolitical' is itself a highly politicized stance, a realization Murphy would not achieve for at least another five years. Having finally abandoned political journalism, Murphy was prepared to purge, with deliberate self-mockery, the memory of his worst moment as a ministerial hack. The retention of the joke is significant because the 1786 Works also represent a very systematic attempt to rewrite his own career.

This rewriting has not helped Murphy's posthumous reputation. Various learned commentators and even editors appear to have conspired over recent years to offer Arthur Murphy a blandly appreciative kiss of death. It is true that Richard Schwartz, in a preface to the Scholar reprint of Murphy's plays remarks: 'in the variety of his literary accomplishments and the consistency of his stylistic deftness, he might fruitfully be compared with Goldsmith.' (He might be, but of

8 John Brewer, Party Ideology and Popular Politics at the Accession of George III (Cambridge, 1981), p. 157.

9 The Plays of Arthur Murphy, ed. with an intro. by Richard B. Schwartz, 4 vols (London, 1979), i, p. vii. 

AND VERSIONS OF THE APOLITICAL

course he is not.) Moreover, Schwartz delivers the coup de grace with the final verdict: 'He is a reliable writer.' ${ }^{10}$ The authors of this article are interested neither in praising nor burying Murphy, but rather excavating a less reliable Murphy, a Murphy who cannot be relied upon to provide safe, stable, or consistent literary products. His studied and self-contradictory pose of being 'apolitical' is, we believe, the key to his continued fascination, a fascination that depends on reconstituting and remembering a polemical Murphy whom Murphy himself sought to dismember.

What does survive (though not unscathed) within the 1786 works is his early magazine The Gray's Inn Journal. This stubbornly light-headed and eclectic Saturday paper is governed by the mercurial narrator 'Sir Charles Ranger'. A fascinating feature of this paper is its repeated and untenable claim to be 'apolitical'. Like his close contemporary Oliver Goldsmith, Murphy was struck by what he saw as the destructive factionalism of the English, the factionalism deplored by Goldsmith in The Traveller. Even in the context of mid 1750s British parliamentary politics (possibly the most quiescent and least interesting politics of the century ${ }^{11}$ ), Murphy observed that party zeal had been displaced rather than eroded (No. XXX, 12 May 1753):

The spirit of party is so interwoven in the constitution of an Englishman, that all
attempts to extinguish it must inevitably fail of success. It may indeed be diverted,
but will not admit of being eradicated. ${ }^{12}$

The paper then goes on to describe the displacement of party zeal on behalf of various stage players. The Garrickeans and the Barryists are at loggerheads. The Quinites remain potent, and he makes an intriguing reference to the Sheridanists, a party distinguished by their obsessive interest in pronunciation. The Sheridan reference does not appear however in the 1753 original paper as Thomas Sheridan had yet to emigrate to England or publish anything related to pronunciation. Thirty years later, while formalizing his own literary image, Murphy clearly believed that Charles Ranger was belatedly entitled to a prescient knowledge of Thomas Sheridan's famous elocution campaigns (a further example of Murphy's determination to rewrite history). Whatever form of factionalism he is describing, Murphy evidences a mixture of fascination and horror. Even when describing this displaced form of political activity, Murphy feels the need to state his lack of party affiliation: 'I defy my greatest enemies to prove, that I ever gave a clap or a hiss, but according to the dictates of my conscience.' ${ }^{13}$ The tone of the disclaimer however suggests that Ranger is a principled exception to a general factional rule.

In terms of its eclectic and sometimes demotic range, Sir Charles Ranger's

10 Ibid., p. xii.

11 For an opposing view of the decade, see J.D.C. Clark, The Dynamics of Change: the Crisis of the 1750s and English Party Systems (Cambridge, 1982).

12 The Works of Arthur Murphy, 7 vols (London, 1786), v, p. 248.

13 Works, v, p. 253-4. 
Gray's Inn Journal is a (very belated) successor to Ned Ward's The London Spy (1699-1700), and like Ward, Ranger is obsessed with London's clubs and Londoners' clubbability. ${ }^{14}$ In his seventeenth number of the Gray's Inn Journal (10 Feburary 1753), Murphy described 'The Robin Hood Society', in a piece designed to poke fun at the eclectic pomposity of English controversial culture, highlighting its most appallingly democratic aspects. The inclusive nature of this club proves its own undoing. The club puts a five minute time limit on all speeches, making it fit only for soundbites. Murphy enjoys the Robin Hood Society and returns to it in a later number (No. LXII , December 22 1753):

\begin{abstract}
All degrees and ranks of men crowd to this place. The love of knowledge has pervaded every breast, insomuch that wisdom scorns all distinction of persons, and we may hear an unshod shoemaker rejudge the works of creation; a taylor, out at elbows, demonstrate that a remnant of all shall be saved; an attourney, who has lost his INSTRUCTOR CLERICALIS, bring $a$ writ of error against revelation; a Philomath from ABERDEEN set forth the dangers of lawn sleeves to both church and state; and a cobbler solve a knotty point, and settle the most abstruse speculation. It is here that the moral government of the universe is called in question, and the fitness of things, and the eternal rule of right, are established or refuted, according to the different genius, the tempers, and complexions of the several disputants. ${ }^{15}$
\end{abstract}

The point that Ranger makes is that political, philosophical and theological controversy had become the business of a motley crew who had all failed at their own trades. London clubmen literally cannot mind their own business: they are Quidnuncs and Razors all. Implicitly Murphy reinforces the ancient but still potent idea that trade is inherently antipathetic to political participation (and vice versa). Those who are required to focus on a particular economic activity are most laughable when attempting to chart a broad political view. Meanwhile, the specific political agenda of this debating society is wittily outlined in the speech of one of its most representative members:

OLIVER CANTWELL: King James I was the worst Monarch that ever sat on the throne of these realms. He was a pedantical, grammatical, pragmatical, tyrannical King and his son Charles was deservedly brought to the block by that great man Oliver Cromwell. The seeds of popery was sown in all the Stuart race; the Jesuits know this perfectly well, and if there is one here at present, let him rise and contradict me if he can. ${ }^{16}$

Cantwell is a seventeenth century relic (psychologically and syntactically imbalanced), one who has never been reconciled to the supposedly perfectly

14 Howard Troyer remarks: 'The prevailing mood of The London Spy is one of light-hearted amusement and supercilious contempt', in Ned Ward of Grub Street: A Study of Sub-Literary London in the Eighteenth Century (London, 1968), p. 37.

15 Works, vi, p. 92.

16 Works, v, pp. 142-3. 
balanced constitution which magnanimously allows him to speak his own mind. Needless to say there are no Jesuits present, so no one rises to contradict him. (Murphy was peculiarly sensitive to anti-Jesuit hysteria having been educated by Jesuits at St Omer). While complaining that the constitution is in danger, Cantwell and his kind are themselves, according to Murphy, the greatest danger to the constitutional settlement, using defensive rhetoric for offensive ends, constantly crying up phantom threats to claim unprecedented liberties.

According to Murphy, the five minute time limit enforced at the club, together with its inclusive membership, illustrates how the broadening of debate occurs continuously with its becoming more and more shallow; as fragmentary and discontinuous slogans take the place of sober reflection and depth of reasoning is no longer to be regarded. The sentence structure used by Robin Hood discussants reflects this belief, providing sentences that are brief, brittle and assertive along with rambling sentence-paragraphs which lose themselves in sub-clauses. Murphy includes reports of several such meetings in order to justify his point. One report concludes with an agenda for the next assembly:

The questions, Gentlemen, (pray gentlemen, be silent) for the next night is

Whether ADAM and EVE had the venereal disease, as we derive corruption from them.

Signed Wagstaff.

Whether the greater number of cuckolds in England, than in Ireland, is owing to the men or the women.

\section{Signed Wagstaff.}

Whether angels look best in a morning or an evening?

Signed Wagstaff.

Whether such an assembly as this would be tolerated in any other christian country?

Signed Wagstaff.

Gentlemen, I wish you a good night.

ADJOURNED. ${ }^{17}$

Murphy sees no difference between democracy and cacophony. The more voices speak, the fewer people listen, and rational decision-making becomes impossible.

17 Works, v, p. 148. 
The political subject (ideally conceived) is a reflexive creature. The Robin Hood men suffer from a malnourished subjectivity, incapable of evolving so as to absorb and synthesize competing interests and opinions. Only the leisured classes, detached from the particularities of a specific trade, can be trusted to do that. Yet, this powerfully reactionary attempt to exclude people from political participation is, apparently, part of an avowedly 'apolitical' project.

Although the Robin Hood Club sounds like an invention, James Boswell records visiting the club in 1763, and its existence and peculiar structure are well attested. ${ }^{18}$ All printed accounts of the club are hostile, stressing both the plebian membership and the over-representation of the London Irish. ${ }^{19}$ The club is even cited as a place where the young Edmund Burke tried his eloquence.$^{20}$ Notably, Murphy nowhere calls for this assembly itself to be suppressed, merely mocked. The Robin Hood confederacy is only dangerous if taken seriously. Toleration is a virtue, and Murphy suggests that those who tolerate but mock these merry men are themselves far more tolerant than the Oliver Cantwells of this world. Politically therefore, Murphy is making an appeal not for proscription but rather the marginalization of popular attempts to influence 'public opinion' ${ }^{21}$ At a time when definitions of 'the people' proved, for political purposes, both porous and expansive, Murphy's key concern is to refute the belief that literacy or access to newspapers constitutes any form of democratic entitlement. The fact that the following decade of successful Wilkite agitation put Murphy squarely on the losing side of history should not detract from the vigour of his conservative position, a position that he defends for the precise duration of the Seven Years War.

Murphy's explicitly 'political' writing began with The Test (1756-57), a weekly anti-Pitt and pro-(Henry) Fox paper, issued every Saturday for a span of thirty-five weeks. In the sixth issue, he cogently offers his assessment of the political feelings of mid-century Britons:

The life of an author has been called a state of warfare upon earth; but of all authors there is not one who has so much reason to subscribe to the maxim as the political writer, because each of his readers is either a patriot, or an old-ministry-man, or a whig, or a tory, or, in short, of some party or other, and very unreasonably expects that a writer is to conform to the passions and prejudices, that have already

18 Representative sources include Timothy Scrubb, Genuine and Authentic Memoirs of the Stated Speeches of the Robin Hood Society (London, 1751), and Richard Lewis, The Robin Hood Society: A Satire (London, 1756).

19 Samuel Foote, The Orators. In which is introduced the Tryal of the Cock-Lane Ghost and a view of the Robin-Hood-Society (Dublin, 1762).

20 John Timbs, Clubs and Club Life in London (London, 1872), pp. 168-9.

21 As Jürgen Habermas puts it: 'Within the framework of constitutional and political science, the analysis of constitutional norms in relation to the constitutional reality of large democratic states committed to social rights has to maintain the institutionalized fiction of a public opinion without being able to identify it directly as a real entity in the behaviour of citizens', The Structural Transformation of the Public Sphere: An Inquiry into a Category of Bourgeois Society, trans. by Thomas Burger and Frederick Lawrence (Cambridge MA, 1989), p. 237. 
taken root in his own mind . . . Amidst the diversity of opinions, occasiond by this contrariety of attachments it is impossible for the author of the TEST to please our British statesmen of all denominations; thus much he will take upon him to say , that he has always pleased his own sense of honour, by adhering invariably to the cause of truth, and endeavouring to procure an amicable coalition, of all our most eminent statesmen, and thereby restore the nation to its old good Nature; and its old good Humour, which, under heaven, which can be the only means of saving us in the present dangerous crisis of our affairs. ${ }^{22}$

With the aim of restoring the nation to 'old good Nature' combined with a sense of some 'present dangerous crisis', Murphy writes in the same alarmist and paranoid vein as John 'Estimate' Brown, whose pamphlet An Estimate of the Manners and Principles of the Times (1757) put forward the prognosis that southern Britons were 'rolling to the Brink of a Precipice' due to the prevalence of a 'vain, luxurious, and selfish Effeminacy' ${ }^{23}$ Unlike Brown, the sort of pusillanimity which Murphy sees troubling the national imperial agenda of trade and conquest does not stem from those men who 'sit the whole morning under the operation of the curling tongs; who are...seen on the roads about London lolling in post-chaises' but more alarmingly is to be found 'among those who ride, and who are in other respects firm and manly. ${ }^{24}$ Rather than being thoroughly effeminized, Murphy likens mid-century Britons and more specifically, Pittites, to the Carthaginians; situating them as a race of men who are not strictly speaking 'effeminate' as Brown would have it, but can, nonetheless, be counted as 'the most abject, desponding people upon earth, when they meet with any unprosperous events of war; haughty, elated, and arrogant in prosperity, and in adversity mean, prostate, and despairing' ${ }^{25}$ In such an unstable and fickle political world, Murphy is convinced that 'all degrees and ranks of people' will side with his assessment of Pitt or the 'Man-Mountain' (as he is dubbed) and the 'Mock-Patriotism' of his patriot-junto. ${ }^{26}$

A significant part of Murphy's rhetorical success in The Test (and something which he did not have recourse to in the later The Auditor) owes to his rehearsal of an image of the aged George II as a feeble and weak monarch, desperately in need of protection. As Murphy saw it, The Test would put an important check on the self-interested and self-serving actions of those Pittite 'Janizaries' who had 'besieged the throne' and proclaimed themselves "The Keepers of the liberties of ENGLAND". ${ }^{27}$ Much of the anti-Pitt material in The Test involves the same sort of invective and personalized political satire, which Murphy would later find objectionable in The North Briton. In the ninth and tenth issues of The Test, Murphy strategically conflates and confuses the metaphor of the 'body politic'

22 Arthur Murphy. The Test, Number VI. Saturday, December 18, 1756 (London, 1756-7), p. 25.

23 John Brown. An Estimate of the Manners and Principles of the Times (Dublin, 1757), pp. 12, 20.

24 Murphy. The Test, p. 178.

25 Ibid., p. 178.

26 Ibid., p. 30; p. 91 ; p. 22.

27 Ibid., p. 30. 
with that of the 'body natural' before proceeding to outline how Pitt's gout as left him 'stretched under a canopy of disease'; a condition that has caused a breach in public affairs. Bodily infirmity is conflated with political sterility and decay, a 'shameful state of inaction' that is cited as the root cause of the present and alarming national enervation. ${ }^{28}$ As the issues progress, jokes on Pitt's gout become much more laboured and harsh. In one such instance, Murphy relates the story of Monsieur de Zulichem who used to administer 'MOXA' (an Indian weed) to his gout. The method of administering the 'cure' says more about political prescriptions than it does about any sort of medicinal benefit:

\begin{abstract}
MOXA is an Indian weed, and the way of applying it was to form it at the bottom as broad as two pence, and terminating in a point at the top; in this manner to place it on the part affected, and with a match (also made in the East-Indies) to light the MOXA, and let it burn down the skin, till entirely consumed. This it seemed repelled the humours. ${ }^{29}$
\end{abstract}

In yet another conflation of the body-natural with body-political, Murphy suggests that instead of reading that Pitt is bed-ridden and official business is therefore on hold, with the help of the exotic 'Moxa' plant, readers might 'have the satisfaction of reading a paragraph now and then, importing that the right honourable has burnt his MOXA, and the national business will not be at a stand above a week or longer' ${ }^{30}$ Intriguingly, the medicinal moxa plant and the match are marked as products of the colonies, of the very spaces that Pitt is supposedly neglecting through his political inaction and self-interest. If the colonies provide the necessary restorative properties for the body-general, than inattention to them can only mean a worsening of the malaise of the body politic. Simply put, Murphy contends that if Pitt cannot keep his own ailments in check, then he is unlikely to succeed at restoring the nation to its proper vigour and strength.

If the anti-ministerial paper The Test is more successful as a political essaysheet than the later pro-ministerial paper The Auditor, it is due to Murphy's performance of the seemingly contradictory position of consistently attacking Pitt, the 'great Commoner', while simultaneously aligning himself with the interests of the city-merchants. As a result of Pitt's mis-administrating of events, the merchants of London have received little protection for their commerce and 'their ships have been cut away out of their very harbours'. ${ }^{11}$ Pitt, like Bute in Wilkes's North Briton, is imaged as a man filled with private ambition, with an 'uncontrollable lust not of serving, but of subjecting the public'; as a man who undeservedly holds 'a monopoly of power, to the exclusion of another, willing and able to serve the same public, who was never known to have disserved it, cannot be reconciled to any ideas of true virtue or good sense' ${ }^{32}$ Such an assessment of

\footnotetext{
28 Ibid., p. 37; p. 54.

29 Ibid., p. 65.

30 Ibid., p. 66.

31 Ibid., p. 93.

32 Ibid., pp. 58-59.
} 
Pitt could easily be mistaken for one of the many anti-Buteite pieces in the pages of The North Briton. Extending this anti-Pitt sentiment, Murphy spends some time rehearsing the loss of Minorca under Pitt's stewardship. Rather than adding to the effeminophobic and vituperative ridiculing of Admiral John Byng (who was later court-martialed and executed for failing to protect Minorca), Murphy chooses to reveal anti-Byng propaganda to be a smoke screen for the internal inadequacies of the administration:

notwithstanding the unpopular and unconstitutional methods made use of to screen the unhappy admiral, and to make royal justice look like cruelty, that the loss of Minorca was an unprosperous event of war, and not owing to disaffection, cowardice or negligence at home, whatever share these three motives may have had in the miscarriage in the Mediterranean; it will appear that undoubted intelligence was then actually in the hands of the ministry, of the plans laid by marshall Belleisle for an invasion of this island; and surely if the gout threatens to attack the stomach, no man will be so idle as to run the risque of the nobler parts for the sake of an inflamed toe..$^{33}$

For Murphy, Pitt's patriot-junto are simply not equipped to deal with the present state of national affairs, having allowed the 'sinews of the constitution' to become more 'enfeebled and relaxed' ${ }^{34}$ It is not Byng who should be cited as an embodiment of national pusillanimity, but rather the Carthaginian administration itself.

While Murphy claims to have the interests of the city-merchants in mind, he stops short of attempting to win over Pitt's popularity base, viewing those middling to inferior class citizens as having no real stake in the political affairs of the state. In the thirtieth issue of The Test (June 4, 1757) Murphy inserts a letter he received (supposedly unaltered), which chastises him for writing in a 'sportive vein...too light and desultory, against the unanimous opinion of the MOB, as you have been pleased to call that part of the people, who have busied themselves in our national concerns' ${ }^{35}$ The fictional letter writer goes further to suggest that he:

thinks it praise-worthy in mechanics, whose lot in life is to get their bread by industry, to relinquish their stations behind their counters, and run about to coffeehouses, and every place where entire but, or punch in small quantities is displayed in capitals on the windows, earnestly enquiring, 'Well, what news? Who are to be ministers? \&c. To neglect their own domestic affairs, and without being called upon, unsolicited, unplaced, and un-pensioned, voluntarily to become politicians of the first magnitude, and generously to undertake the business of the nation is most assuredly a strong instance of publick spirit in a set of booksellers, attorneys, and the underlings of man-kind in general. ${ }^{36}$

33 Ibid., p. 120.

34 Ibid., p. 128.

35 Ibid., p. 170.

36 Ibid. 
This letter provides a clear anticipation of the character of Quidnunc ('What News?') and the plot of The Upholsterer. If the irony of this paragraph was lost on any readers, the letter writer continues to mock the political pretensions of the inferior set, by suggesting that a 'common-council' comprised of such men should be adhered to, should the privy-council be deemed 'not sufficiently enlightened to advise proper measures' ${ }^{37}$ And in an effort to really drive the point home, the fictional letter writer surmises that 'when the most exalted genius and extensive experience of men of birth, education and fortune prove deficient, it is high time we should be directed by dullness, ignorance, and folly. ${ }^{38}$ If this rejection of the 'mobocracy', as Murphy termed it, did not sink The Test, it is because the paper was able to negotiate a particularly clever passage between anti-Pittite sentiment while also acknowledging Pitt's mercantile support base. With The Auditor came a reversal of positions. No longer writing in opposition to the administration, Murphy found himself at the other end of the spectrum, defending not a popular minister, but one who was becoming increasingly disliked, being figured as foreign and disinterested. His tactic in The Test of rhetorically constructing himself as a guardian of an ailing king was also unavailable, while George III was frequently depicted as a schoolboy being manipulated and influenced by his former tutor Bute. With a loss of these rhetorical tools, Murphy naturally spent much time focusing on popular politics, especially as it served to bolster the diverse Wilkite agitation. The difficulty with such an anti-mobocratic view in the early days of George III was that it amounted to a wholly out-of-touch apolitical posture, one that left Murphy's political propaganda unable to engage with the core of what carried the Wilkite political agitation so far.

Even the most cursory reader of The Auditor would have been familiar with Murphy's frequent, albeit, inconsistent rhetorical strategy of political selfeffacement. Murphy's anxiety about asserting his political position often found expression in disclaimers of political authority, which prefaced the main body of pro-Buteite arguments. While Murphy is decidedly pro-ministerial, he is careful to remind his readership that he, ultimately, is not on the receiving end of any substantial financial or reputational gain from this alignment. Rather, it is a love of the truth and of his country that has lead Murphy to obtain 'the honour of having charged himself with so troublesome an employment, UNSOLICITED, UNPLACED, UNBRIBED, AND UNPENSIONED' ${ }^{39}$ Curiously, Murphy deploys the exact same language here to defend his own engagement in politics as he did when critiquing mass political interest earlier in The Test..$^{40}$ This rather bland and customary disavowal of a personal agenda comes just weeks after Murphy's own self-appointment in The Auditor as the sole watcher or guardian of the contours of public political debate:

37 Ibid., p.170.

38 Ibid.

39 Ibid., p. 5.

40 See A. Murphy, The Test, p. 170. 


\begin{abstract}
What therefore mortifies me is, that the spirit of party, which prevails too much among us, should make it necessary for the AUDITOR to continue to watch over the understandings of the good people of England, who, it must be avowed, are such coarse feeders in politics, that the vilest provisions, if they happen to be seasoned highly with palatable ingredients of a poisonous nature, will ever go down with them, and hence the necessity of supplying them with the wholesome fare, that they may not prey on garbage. Party rage has been very sensibly called the madness of many for the gain of the few. ${ }^{41}$
\end{abstract}

Ever since the twenty-second issue of The Test (and indeed in The Gray's Inn Journal), Murphy had identified 'Party-rage: the madness of many for the gain of a few' as a peculiarly English vice while asserting (unconvincingly) his own immunity from the general contagion..$^{42}$ His self-appointment as neutral 'auditor' did not go unnoticed or unchallenged. John Cæsar Wilkes, the pseudonymous editor of The Political controversy (1762-1763), a weekly annotated bumper edition of both ministerial and anti-ministerial papers, immediately fastened onto Murphy's positioning, asking: 'and pray, Sir, who set you to watch over the understandings of other people, when you so frequently give incontestable proofs of the fallability of your own!---' ${ }^{43}$ Murphy's self-posturing as the regulator of political debate is thoroughly at odds with a burgeoning mid-century climate of inclusive political discussion among the middling and lower urban classes in London. In fact, as the editor later makes clear, Murphy's positioning goes against the very structural function of an edited and collected reissue of political papers, such as the Political controversy: 'How necessary was our undertaking to publish the debates of these political gentry at one view; and of submitting their different merits to the determination of the public. Without such a plan, people might be led into an opinion that there was one man of sense in the kingdom, but the AUDITOR. Self sufficience, Mr. Auditor, is no more a sign of sound understanding, than recrimination is of a good cause' ${ }^{44}$

Murphy's seemingly pompous admonitory posture was set in direct opposition to the far more entertaining self-presentation of his principal antagonist. Kathleen Wilson remarks on the theatricality of popular politics in the early 1760 s by noting that Wilkes ' $\mathrm{knew}$ how to play the fool in a ceremonial age' ${ }^{45}$ Wilson comments upon and extends the observations of John Brewer who considers that

The Artisan, wage-earner, small employer and craftsman were naturally disposed towards Wilkes because he gave them status and consequence that no-one had ever offered them before... The pleasure that Wilkes offered was at the expense of the powerful, but in a very different sense. Their defeat, humiliation, their

41 Ibid, Number VI. Monday, August 19, 1762, vol. i, p. 192.

42 A. Murphy, The Test, p. 128.

43 Ibid.

44 Ibid.

45 Kathleen Wilson, The Sense of the People: Politics, Culture and Imperialism in England, 1715 1785 (Cambridge, 1995), p. 386. 
ridiculousness in the face of Wilkes' provocative conduct was the source of his supporters' enjoyment. ${ }^{46}$

Wilson and Brewer share the decisive insight that Wilkite radicalism is significant not in terms of stated political aims or achievement but in terms of its infectious 'enjoyability', its ability to generate an upbeat and good humoured popular taste for political engagement. The detailed research of Brewer and Wilson helps to tease out one of Jürgen Habermas' more promisingly paradoxical contentions: 'The public's understanding of the public use of reason was guided specifically by such private experiences as grew out of the audience-orientated (publikumsbezogen) subjectivity of the conjugal family's intimate domain (Intimsphäre). ${ }^{97}$ In other words, the very terms of petty-bourgeois domesticity which the conservative Murphy regarded as grounds for political exclusion were being reorganized to legitimate new forms of civic inclusion..$^{48}$

From the outset therefore, one obvious and unfortunate disadvantage for Murphy's career as a political writer was not his position as a pro-administration propagandist, trapped in a social and political climate that was rapidly becoming increasingly hostile to the 'Peace party' and the eventual terms of the Treaty of Paris, but rather his forceful dismissal of the validity of this sort of popular inclusive debate. As both Churchill and Wilkes well understood, Murphy was disadvantaged by his routine abhorrence at the sheer volume of 'popular clamour' and 'violent. . . prejudice', a distaste that worked to sufficiently isolate him from the sort of popular mood of political engagement that fuelled and sustained what was otherwise an incoherent and fragmentary Wilkite political agenda. ${ }^{49}$ Curiously enough, Murphy cannot be said to have been alone in his weariness of this growing political consciousness. Before taking up a role as co-editor of The North Briton, his antagonist Charles Churchill articulated a similar distrust of the growing political awareness in his poem Night (1761). In addition to reducing the Seven Year's War (1756-1763) to the level of an absurd and futile project, Churchill proceeds to mock the involvement and contribution of ordinary men and (particularly) women within political culture:

No private joy, no private grief they know,

Their soul's engross'd by public weal or woe,

Inglorious ease like ours, they greatly scorn:

Let care with nobler wreaths their brows adorn.

46 Brewer, p. 199.

47 Habermas, Structural Transformation of the Public Sphere, p. 28.

48 However, as Brian Cowan has noted (explicitly referencing The Tatler's version of the politicised upholsterer in an anti-Habermasian critique of the notion of an early eighteenth-century coffeehouse public sphere), eighteenth-century periodical writers frequently declared their intention to regulate and even inhibit the scope of political discourse rather than expand it. Brian Cowan, 'Mr Spectator and the Coffee House Public Sphere', Eighteenth-Century Studies, 37: 3 (Spring, 2004), pp. 345-366.

49 Murphy, The Test, Number X. Monday, December 20, 1762, vol. ii, p. 357. 


\author{
Gladly they toil beneath the statesman's pains, \\ Give them but credit for a statesman's brains. \\ All would be deem'd e'en from the cradle fit \\ To rule in politics as well as wit. \\ The grave, the gay, the fopling, and the dunce, \\ Start up (God bless us!) statesmen all at once (209-18)..$^{50}$
}

Whereas Churchill would abandon any reservations concerning this growing political awareness as sections of it proved to be a driving force behind the Wilkite movement, with politically aware citizens being constructed in later poems such as Independence (1764) as those solely "... fit to bear / The weight of Empires; Fortune, Rank, and Sense" (564-65), Murphy seems to have never been able to warm to these developments and finally abandoned politics for the theatre in the 1760s. Murphy's colleague in pro-administration propaganda, Tobias Smollett toed a similar line in The Briton, albeit, his demarcation of London's mobocracy tactically displaces the mob as existing firmly outside of the bounds of what could be properly considered an English political metropolitan community; a rhetorical position which serves to diminish the validity of such political engagements:

\begin{abstract}
By the English people, I do not mean the base, unthinking rabble of this metropolis, without principle, sentiment, or understanding; the undistinguishing babblers that open on every scent with equal clamour; the vilest stubble of faction, supplying fuel to every incendiary. To the abandoned, the idle, and the profligate, scenes of tumult and dissention will always be agreeable. The English people, considered a respectable community, are the honest, sober, the thriving sons of industry, who have an interest in the country they inhabit; who have a sense to value the blessings they enjoy. They compose the strength and riches of the nation; consequently their ease and happiness ought to be the great object of every administration..$^{51}$
\end{abstract}

Smollett's drawing of a careful distinction between the 'unthinking rabble' and a true English citizenry is of course a tactical response to the Wilkite movement's rhetorical expansion of political franchise to the metropolitan middling and inferior set. Smollett is keen to fasten onto the more boisterous elements of the Wilkite/Pittite political endeavour as a way of discrediting such men from the public sphere of political action and debate. In contrast, as a play such as The Upholsterer bears out, Murphy's disdain for the mob remains less specific and more encompassing.

Murphy repeatedly blamed politics for his professional setbacks and his early hagiographic biographer, Jesse Foote, agrees while treating his subject as only ever the victim of factional controversy. Reviewing the 1764 London theatre session, Foote remarks: 'both of these plays [No one's Enemy but his Own, and What We must All come to] were introduced on the stage on the same night,

50 Charles Churchill, Night: An Epistle to Robert Lloyd, in Douglas Grant (ed.), The Poetical Works of Charles Churchill (Oxford, 1956), pp. 49-61.

51 Tobias Smollet. The Briton, No. 6. Saturday, 3 July 1762, in Byron Gassman, O.M. Brack, Jr., Leslie A. Chilton (eds), Poems, Plays and The Briton (Athens, Georgia, 1993), p. 266. 
and both were dismissed in consequence of the political ferment of the day having penetrated the walls of the theatre' ${ }^{52}$ Murphy's reputation as a tool of the administration had created a long-standing claque determined to shout down whatever he had to offer them.

However, Murphy's supposed distaste for political engagement is hardly borne out by the facts or by such poems as 'The Naiads of the Fleet Ditch' (1762), a poem attacking the critical and poetic confederacy of Churchill, Robert Lloyd and George Colman:

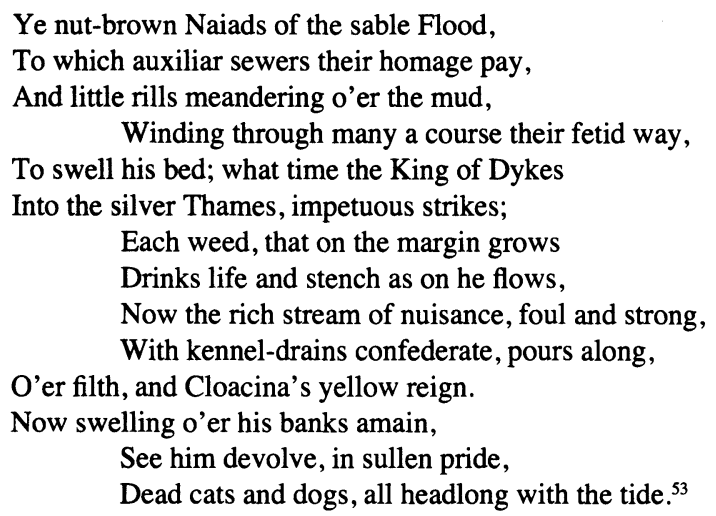

Responding to this sort of faecal mud slinging, one pseudonymous 'Irish' poet took it upon himself to compose The Murphiad (1761), which charmlessly decides to abuse the poet's mother, dramatizing an illegitimate birth for its protagonist: 'our hero [...] made his entry to this breathing world near the Bog of Allen; a circumstance that at once accounts for his extraordinary genius in the Sh-tten stile'. ${ }^{54}$ Murphy's mother is resolved upon infanticide, but is dissuaded from this course of action by the prophetic speech of some form of mud-goddess:

Amidst an host of enemies opprest,

One formidable bard shall rear his crest;

Churchillo call'd --- an undistinguished name,

Till then unknown to art, unknown to fame;

Who with a heart and club of English oak,

Shall make Shillalee quake at ev'ry stroke:

But favor'd still by dullness, and by me,

Thy son shall rise superior in degree;

By art and impudence maintain his right,

And put his dread antagonist to flight:

Then while the flying foe is still in view,

Shou'd ever rage induce him to pursue;

52 Jesse Foot, The Life of Arthur Murphy (London, 1811), p. 192.

53 Ibid., pp. 196-7.

54 The Murphiad, a Mock Heroic Poem by Philim Moculloch (London, 1761), p. ii. 
Shou'd A-th-r on the heels of $\mathrm{Ch}-\mathrm{ch}$-ll come

Resolv'd to ratify his rival's doom:

And in the famous ditch, where Pope before

Plung'd Oldmixon and Smedley o'er and o'er;

Should he with Popish zeal attempt the same,

To flounce him in the realms of filth and shame;

With cautious prudence he must pause thereon,

Lest with the foe he tumbles headlong down:

There wallowing in the mud as black as ink.

The more he stirs, the more his muse shall stink;

Till eminent in filth, the Naiad throng

Shall chant his praises in some filthy song;

And eager to create him sov'reign Lord,

Shall crown him with diadem of $\ldots . . .55$

This attack on Murphy, which read together with 'The Naiads' is almost embarrassingly indebted to the long influence of The Dunciad, is both disgusting and hibernophobic but it is hardly unprovoked. Murphy had been the first to enter the sewer and was in no position to complain of having been more than repaid in kind. Fortunately there was to be no way down from this last exchange and this particular spat was discontinued following one more (relatively temperate) poem: 'Expostulation', by Murphy. The trouble had initially started when Murphy was slightingly referred to in Churchill's blockbuster satire The Rosciad (1761), but Murphy's pen is far more abusive than Churchill's disdain warranted. Later, in the thirty-fifth issue of The North Briton, Murphy's Florida turf gaffe would occasion a further derogatory reference to the author's 'native bog of Allen'. Literally making Murphy out to be a bog-man, Wilkes connects the softness of peat with Murphy's 'soft, tender mind', as if his Irish birthplace has somehow left him with an inherent weakness of constitution. ${ }^{56}$ Although Murphy did not promote his Irishness, Wilkes uses this reticence to suggest an ultimate disloyalty to his mother country: 'To carry on that trade, I dare say he would be ready to bargain even for his dear natale solum, and would no more scruple to begin a treaty to sell his country, than he did to sell himself. ${ }^{, 57}$ Just as Murphy prostitutes his pen for the administration, Wilkes suggests that he would do the same to his native Ireland.

The Florida Peat affair marks the end of Murphy's oscillation between the possibilities of being either a reactionary comic or a comic reactionary, opting securely for the former. No longer would he continue to use comedy to serve

55 Ibid., pp. 17-18.

56 John Wilkes. The North Briton. Revised and Corrected by the Author. Illustrated with explanatory notes, and a copious index of names and characters. In Two Volumes (Dublin, 1764), p. 199. Kathleen Wilson comments on the politics of effeminacy in the Wilkite era thus: 'The Wilkite cult of resistance then, like radical contract theory itself, could express an acute hostility toward both the effeminate and the feminine in the body politic that sought to close down the gender identities available for political subjects in order to enlarge and legitimate more expansive notions of citizenship for the middle classes', Wilson, The Sense of the People, p. 225.

57 The North Briton, p. 199. 
a reactionary political cause but he would continue to use reactionary comedy to secure popular literary applause. No longer writing directly at the behest of conservative politicians, he became, more indirectly, a far more successful conservative writer.

One final question concerns Murphy's recurring sense of the English as a people with little to complain about who are addicted to complaining, a sense he shared with his contemporary and compatriot Oliver Goldsmith. Goldsmith and Murphy, two Irish midlanders of similar ages and backgrounds, each felt able to claim a degree of distance and 'objectivity' when describing England's political objectivities. Indeed, Goldsmith's 1760 Citizen of the World papers, like the narrator of The Traveler (1764), are able to judge British (or English) culture from the vantage point of an informed foreign eye. Similarly, Murphy's The Gray's Inn Journal is a work of highly condensed eclecticism, cramming discussions of aesthetics, theology, politics, theatre criticism, fashion, ethics, manners etc into a very few pages and written (we can be sure) in haste, as the work of an actor, lawyer, dramatist and polemicist, someone of dubious and foreign origins who clearly cannot mind any one business. His own journal cannot help therefore but be accused of being itself a form of Robin Hood Society, a pot-pourri of rapid reflections on all manner of topics and an impudent assertion of a right to pontificate on every conceivable subject. By reporting the impudent breadth of political debate, the reactionary satirist cannot help but contribute to the same tendency. Of course, the practice of enlisting popular agitation in the service of causes that hindsight has labeled reactionary long predates Arthur Murphy. Nicholas Rogers, who distinguishes politicized crowds as 'transgressive rather than subversive' 58 notes that 'crowds did not necessarily follow an oppositional cum radical vector... popular sympathies could conceivably bolster rather than challenge oligarchic regimes. ${ }^{59}$ However, the enlistment of crowds for reactionary ends differs from and is less problematic than the attempt to debate in print the dangerous expansion of the market for political journalism.

The most fascinating aspects of Murphy's comparatively brief career as a reactionary journalist are to do with the way he exemplifies a critical and arguably quite new political paradox. The expansion of political discussion that created The North Briton (and which The North Briton further encouraged) forced those who wished to restrict political participation to engage an ever larger readership, thus undermining their entire political philosophy. ${ }^{60}$ As Kathleen Wilson has noted: 'literacy becomes the test of citizenship and the instrument of political subjectivity itself, and through print culture, both the subject's right to monitor

58 Nicholas Rogers, Whigs and Cities: Popular Politics in the Age of Walpole and Pitt (Oxford, 1989), p. 388.

59 Ibid., p. 378.

60 Brewer observes of the failure of the conservative press of the early 1760 s: 'Neither of the two papers [The Briton and The Auditor] therefore, was very successful. Indeed by provoking the foundation of the North Briton they proved... an actual hindrance to Lord Bute's cause', p. 222. 
the state and his potential for citizen activism were fulfilled. ${ }^{91}$ Such paradoxes of popular conservatism appear to be well understood and ably defended and explained by conservative theorists, yet in the 1750 s and 60 s, these contradictions were fresh, fraught and seemingly insuperable, at least as far as Arthur Murphy was concerned and therefore provide a valuably honest and paradoxical snapshot of controversial culture at an (unknowing) point of radical change.

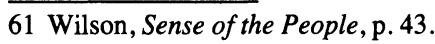

